\title{
Hubungan fraksi area trabekula anterior mandibula dengan kepadatan tulang lumbar spine untuk deteksi dini osteoporosis
}

\author{
Sri Lestari* dan Rini Widyaningrum** \\ *Program Studi Teknik Elektro, Fakultas Sains dan Teknologi, Universitas Respati Yogyakarta, Yogyakarta, Indonesia \\ **Departemen Radiologi Dentomaksilofasial, Fakultas Kedokteran Gigi, Universitas Gadjah Mada, Yogyakarta, Indonesia \\ *JI Laksda Adi Sucipto Km 6,3, Depok, Sleman, Yogyakarta, Indonesia; e-mail: lestari2411@gmail.com
}

Submisi: 29 Juli 2016; Penerimaan: 11 Oktober 2016; Publikasi online: 28 April 2017

\begin{abstract}
ABSTRAK
Kepadatan tulang merupakan indikator osteoporosis, salah satu diantaranya adalah kepadatan tulang pada lumbar spine. Penurunan kepadatan tulang pada lumbar spine mempengaruhi kondisi tulang lain, termasuk tulang rahang bawah (mandibula). Tujuan penelitian ini adalah untuk menentukan prediktor densitas mineral tulang menggunakan citra radiograf periapikal tulang trabekula pada regio anterior rahang bawah. Penelitian dilakukan dengan ekstraksi fraksi area tulang trabekula mandibula yang tercitrakan pada radiograf periapikal digital dari 25 subjek. Pengolahan citra digital pada radiograf periapikal dilakukan dengan menggunakan metode deteksi tepi canny terhadap masing-masing citra radiograf. Region of Interest diseleksi dari citra hasil deteksi canny, sehingga dapat dilakukan pengukuran fraksi area. Uji regresi linier dilakukan untuk mengetahui hubungan antara nilai fraksi area trabekula mandibula dengan tingkat kepadatan tulang pada lumbar spine. Hasil uji regresi linier menunjukkan bahwa nilai fraksi area trabekula mandibula berkorelasi negatif dengan kepadatan tulang dengan kekuatan sedang $(\alpha=0,046 ; R=-0,403)$. Adapun arah korelasi antara nilai fraksi area trabekula mandibula dengan kepadatan tulang adalah negatif $(b=-0,145)$. Fraksi area tulang trabekula pada citra radiograf periapikal dapat digunakan sebagai prediktor kepadatan tulang pada lumbar spine.
\end{abstract}

Kata kunci: canny; kepadatan tulang; mandibula; osteoporosis; trabekula

\begin{abstract}
The relationship of anterior mandible trabecular area with bone mass density of lumbar spine for early detection of osteoporosis. Bone mineral density is an indicator of osteoporosis, including the bone mineral density of lumbar spine. The decrease of lumbar spine bone mass density will cause an alteration in another site, including the mandibular. The aim of this research is to determine the predictor of lumbar spine bone mineral density using trabecular bone image of anterior mandible on periapical radiographs. The research was conducted by extracting the area fraction at mandible trabecular bone using digital periapical radiograph from 25 subjects. Canny edge detection was used in digital image processing for each radiograph. The regions of interest were selected from the image obtained by canny edge detection, so that the area fraction could be measured. A linier regression test was applied to determine a relationship between the area fractions of mandible trabecular bone with the bone mineral density of lumbar spine. The result of linear regression test showed that the area fraction of mandible trabecular bone had a moderate negative correlation with bone mass density of lumbar spine ( $\alpha=0.046 ; R=-0.403)$. The direction of the correlation was negative $(b=-0.145)$. The area fraction of mandible trabecular bone on periapical radiographs could be used as the predictor for bone mass density of lumbar spine.
\end{abstract}

Keywords: canny; bone mineral density; mandible; osteoporosis; trabecular bone

\section{PENDAHULUAN}

Osteoporosis adalah suatu penyakit skeletal sistemik yang dicirikan dengan penurunan massa tulang, perubahan arsitektur tulang, dan konsekuensi klinis berupa kerentanan terhadap fraktur (patah tulang) akibat trauma yang ringan ataupun tanpa trauma. Pada umumnya, fraktur terjadi pada bagian tulang yang mayoritas tersusun oleh trabekula, antara lain pergelangan tangan (wrist), tulang belakang (spine), dan pangkal paha (hip). Kontribusi osteoporosis terhadap angka kesakitan (morbiditas) dan angka kematian (mortalitas) relatif rendah. Namun demikian fraktur osteoporosis membuat penderitanya kesakitan serta mempengaruhi kondisi sosial ekonomi akibat perubahan aktivitas sosial kemasyarakatan dan beban biaya pengobatan bagi penderita dan keluarganya. ${ }^{1}$

Hasil analisa data risiko osteoporosis pada tahun 2005 dengan jumlah sampel 65.727 orang 
yang dilakukan oleh Puslitbang Gizi Depkes RI dan sebuah perusahaan nutrisi dengan metode pemeriksaan Densitas Mineral Tulang (DMT) menunjukkan bahwa 2 dari 5 penduduk Indonesia memiliki risiko untuk terkena osteoporosis. Beberapa penelitian di bidang kedokteran gigi membuktikan bahwa terjadinya osteoporosis pada tulang paha dan/atau tulang belakang akan diikuti dengan osteoporosis pada tulang rahang. Salah satu program pengendalian osteoporosis oleh Kementrian Kesehatan RI adalah penemuan (termasuk deteksi dini) dan tatalaksana kasus osteoporosis. Tujuan dari program ini adalah pelaksanaan deteksi dini pada kelompok masyarakat yang beresiko osteoporosis, sehingga angka kesakitan dan kematian akibat osteoporosis dapat diturunkan. ${ }^{2}$

Salah satu upaya penting untuk menekan angka kejadian osteoporosis di Indonesia adalah dengan melakukan pemeriksaan DMT atau kepadatan tulang pada kelompok yang beresiko tinggi. ${ }^{3}$ Badan kesehatan dunia (WHO) menetapkan bahwa Dual Energy X-Ray Arbsorptiometry (DEXA) merupakan standar baku emas untuk pemeriksaan kepadatan tulang. Namun demikian penggunaan DEXA untuk screening tahunan wanita post menopause mengalami beberapa kendala. Kendala tersebut antara lain adalah mahalnya biaya pemeriksaan dan alat tersebut masih sangat terbatas. Di Indonesia, DEXA pada umumnya tidak terdapat di rumah sakit kecil di daerah atau puskesmas, melainkan hanya terdapat di rumah sakit rujukan atau rumah sakit besar. ${ }^{4,5}$

Di antara masalah yang banyak dialami oleh lansia adalah permasalahan pada gigi dan mulut. Hal ini mengakibatkan potensi lansia untuk mengunjungi dokter gigi cukup tinggi. Kunjungan tersebut dapat bertujuan untuk perawatan gigi berlubang, pembuatan protesa, dan perawatan penyakit periodontal. ${ }^{6} \mathrm{Di}$ sisi lain, lansia juga memiliki potensi untuk mengalami permasalahan pada tulang dan persendian termasuk diantaranya adalah osteoporosis. Osteoporosis merupakan silent desease yang tidak menunjukkan gejala yang signifikan sampai penderitanya mengalami fraktur, sehingga menurunkan potensi kunjungan lansia ke dokter untuk memeriksakan kepadatan tulang. ${ }^{5}$
Hasil penelitian sebelumnya menunjukkan bahwa wanita postmenopause yang mengalami perubahan pada mandibulanya dimungkinkan memiliki resiko osteoporosis atau DMT vertebral yang rendah. ${ }^{7}$ $\mathrm{Hal}$ ini menjadi peluang pengembangan metode deteksi resiko osteoporosis bedasarkan informasi kondisi mandibula yang tercitrakan pada radiograf.

Upaya penegakan diagnosa perlu didukung dengan metode dan piranti yang sesuai. Pemeriksaan radiografi merupakan salah satu metode yang umum digunakan untuk mencitrakan bagian dalam tubuh dengan memanfaatkan radiasi sinar-X. Perangkat DEXA merupakan salah satu modalitas radiografi sinar- $X$ yang digunakan oleh dokter untuk menentukan kondisi kepadatan tulang. Pemeriksaan radiografi juga diperlukan pada perawatan gigi untuk penegakan diagnosa dan penentuan rencana perawatan. ${ }^{7,8}$

Pemeriksaan radiografi yang paling banyak dimanfaatkan pada praktek kedokteran gigi antaralain radiografi panoramik (ekstraoral) dan periapikal (intraoral). Radiografi periapikal merupakan salah satu teknik radiografi dental yang dapat mencitrakan empat hingga lima gigi beserta daerah apikalnya pada satu film rontgen intraoral. ${ }^{9}$ Tulang trabekula rahang bawah (mandibula) dapat divisualisasikan pada radiograf periapikal. Pada tingkat mikro struktur, pola tulang trabekula rahang dapat dihubungkan dengan kondisi tulang pada bagian kerangka lain di dalam tubuh. ${ }^{5}$ Teknik radiografi periapikal dapat dijadikan alternatif untuk memberikan informasi mengenai kondisi tulang trabekula pada mandibula yang diharapkan dapat menjadi indikator dalam deteksi osteoporosis. Pemeriksaan dengan radiografi periapikal relatif tidak mahal dan ketersediaan perangkatnya relatif lebih luas dibandingkan dengan alat DEXA.

Upaya pencegahan osteoporosis memerlukan teknik diagnostik yang tepat. Jika osteoporosis dapat terdeteksi pada fase awal, maka proses penanganan terhadap penyakit ini akan lebih mudah. ${ }^{8}$ Oleh karena itu, upaya-upaya deteksi dini osteoporosis sangat menarik untuk dikaji, termasuk diantaranya adalah kajian mengenai pemanfaatan radiograf kedokteran gigi untuk deteksi osteoporosis. Tujuan penelitian ini adalah 
untuk menentukan prediktor densitas mineral tulang menggunakan citra radiograf periapikal tulang trabekula pada regio anterior rahang bawah. Parameter fraksi area radiograf periapikal mencerminkan kondisi tulang trabekula pada regio anterior rahang bawah, dan nilai densitas mineral tulang diwakili oleh nilai T-score lumbar spine. Sistem deteksi dini resiko osteoporosis terkomputerisasi bagi dokter gigi menjadi tujuan jangka panjang dari penelitian ini.

\section{METODE PENELITIAN}

Sampel penelitian berupa data tingkat densitas tulang hasil scan DEXA pada lumbar spine dan radiograf periapikal digital yang didapatkan dari 25 subjek wanita pasca menopause. Radiograf periapikal yang digunakan dalam penelitian ini telah melalui proses penilaian kualitas (quality assurance) radiografi oleh dokter gigi, sedangkan hasil scan DEXA telah diperiksa dan telah diinterpretasikan oleh dokter spesialis radiologi. Penelitian dilakukan setelah memperoleh surat kelayakan etik (ethical clearance) dari unit etika dan advokasi Fakultas Kedokteran Gigi Universitas Gadjah Mada, Yogyakarta.

Pemilihan sampel dilakukan dengan mempertimbangkan kriteria inklusi dan ekslusi. Adapun kriteria inklusi subjek penelitian adalah wanita postmenopause, yang ditandai dengan sudah tidak mengalami menstruasi secara alami. Menyetujui untuk ikut serta sebagai subjek penelitian dengan menandatangani informed consent. Kriteria eksklusi subjek penelitian meliputi menderita penyakit metabolik (hiperparatioidisme, hipoparatiroidisme, Paget's disease, osteomalasia, renal osteodistrofi, dan atau osteogenesis imperfecta), kanker dengan metastasis tulang, dan atau gagal ginjal, serta sedang mengkonsumsi obat yang mempengaruhi metabolisme tulang (biposponat/bisphosphonates, terapi hormon estrogen, selective estrogen receptor modulators (SERMs)).

Pengambilan radiograf periapikal digital di RSGM Prof. Soedomo menggunakan image receptor PSP (photostimulable phosphor plate) dan dental $X$-ray Villa sistemi medicali Endos ACP CEI (Bologna, Italy) dengan spesifikasi 70 $\mathrm{kVp}, 8 \mathrm{~mA}$, dan 3,2 s. Pemeriksaan DEXA untuk mengukur densitas tulang belakang (lumbar spine) dilaksanakan di RSUP Dr. Sardjito, Yogyakarta menggunakan Lunar Prodigy primo DEXA densitometer (GE Lunar Corporation, Madison, WI, USA) dengan paparan $42 \mu \mathrm{Gy}$ selama 1,27 menit. Nilai densitas tulang dikonversikan menjadi nilai $T$-score untuk menentukan status osteoporosis, osteopenia, atau normal sesuai standar WHO sebagai berikut: nilai T-score lebih dari 1,0 menunjukkan kepadatan tulang normal; nilai $T$-score -2,5 sampai dengan 1,0 dikategorikan sebagai osteopenia, nilai $T$-score kurang dari $-2,5$ dikategorikan sebagai osteoporosis, sedangkan nilai $T$-score kurang dari $-2,5$ yang disertai fraktur akibat penurunan kekuatan tulang dikategorikan sebagai osteoporosis berat. ${ }^{4}$

Pengolahan citra digital dilakukan terhadap radiograf periapikal untuk memperoleh hasil ekstraksi berupa nilai fraksi area. Selanjutnya pada setiap citra radiograf periapikal dilakukan deteksi tepi canny. Untuk memperlihatkan diskontinuitas intesitas dari trabekula, maka digunakan metode deteksi tepi deteksi tepi canny. Pemilihan metode ini merupakan pengembangan dari penelitian sebelumnya yang menggunakan metode Gray Level Run Length. Metode GLRL kurang efektif karena tergantung pada sudut dalam analisisnya, sehingga sulit untuk diberlakukan untuk semua citra radiograf periapikal..$^{10}$ Hasil deteksi tepi canny ditunjukkan pada Gambar 1. Ekstraksi nilai fraksi area dilakukan terhadap Region of Interest (ROI) menggunakan software ImageJ 1.50i Wayne Rasband, National Institutes of Healts, USA (http:// imagej.nih.gov/ij/). ROI yang digunakan yaitu area tulang trabekula regio anterior mandibula pada citra hasil deteksi tepi canny. Region of interest yang digunakan untuk mengukur fraksi area pada penelitian ini adalah area trabekula di bawah gigi-gigi anterior rahang bawah. Penetapan area tersebut ditujukan untuk menyeragamkan area pengambilan ROI. 


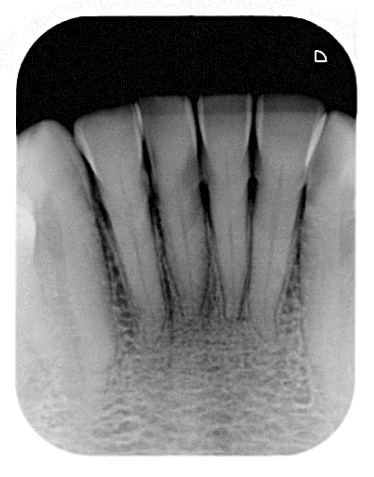

(A)

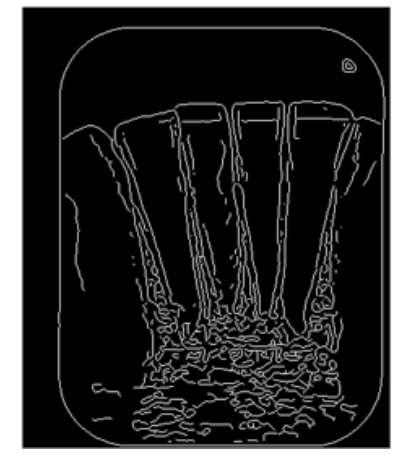

(B)

Gambar 1. Citra radiograf periapikal digital sebelum dilakukan image processing (A), dan citra deteksi tepi canny (B)

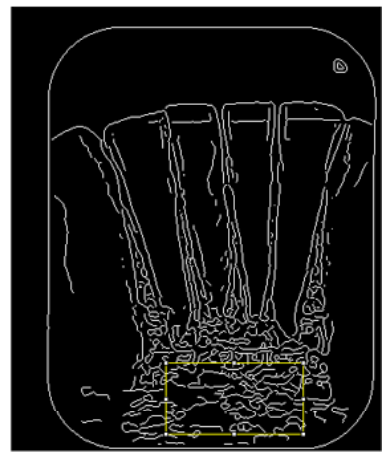

(A)

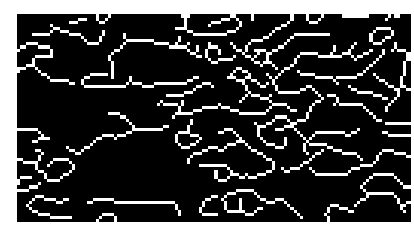

(B)

Gambar 2. Proses seleksi ROI pada tulang trabekula regio anterior mandibula (A), dan hasil crop $\mathrm{ROI}(\mathrm{B})$

Proses seleksi ROI dilakukan dengan validasi dokter gigi yang berkompeten dalam bidang radiologi kedokteran gigi. Seleksi $\mathrm{ROI}$ dilakukan dengan seleksi berbentuk persegi panjang dengan ukuran yang berbeda-beda untuk setiap radiograf. Ukuran ROI menyesuaikan kondisi pada citra. Standar seleksi ROI adalah area pada regio anterior yang menunjukkan trabekula tanpa mengenai akar gigi atau penampakan yang lain yang mengganggu proses analisis (misal: adanya penampakan tumor). Proses seleksi ROI ditunjukkan pada Gambar 2.

Nilai fraksi area diperoleh dari pengukuran luasan fraksi area yang terbentuk pada ROI dibagi dengan total luas ROI. Uji regresi linear antara nilai fraksi area dengan nilai $T$-score pada lumbar spine dilakukan untuk mengetahui hubungan dan kemampuan fraksi area pada mandibula untuk memprediksi nilai $T$-score pada lumbar spine.

\section{HASIL PENELITIAN}

Hasil ekstraksi nilai fraksi area dari tulang trabekula regio anterior mandibula merupakan data numerik dengan skala rasio yang menyatakan perbandingan antara jumlah luas fraksi area yang terbentuk dalam citra ROI terhadap luas total ROI. Adapun hasil scan DEXA pada lumbar spine dinyatakan dalam nilai $T$-score yang merepresentasikan kondisi kepadatan tulang lumbar spine.

Uji regresi linear dilakukan terhadap nilai fraksi area sebagai variabel bebas (independent), dan nilai T-score pada lumbar spine sebagai variabel terikat (dependent). Hasil uji regresi linier disajikan dalam Tabel 1. Korelasi $(R)$ antara nilai fraksi area dengan nilai $T$-score bernilai 0,403 sehingga memiliki kekuatan korelasi pada tingkat sedang. Pengaruh nilai fraksi area trabekula mandibula terhadap nilai $T$-score pada lumbar spine sebesar $16,2 \%$, sedangkan $83,8 \%$ sisanya dipengaruhi oleh variabel yang lain. Nilai $F$ hitung yang diperoleh 
sebesar 4,455 dengan signifikansi kurang dari 0,05 $(\alpha=0,046)$. Dengan demikian model regresi linier nilai fraksi area trabekula mandibula dapat digunakan untuk memprediksi nilai $T$ score lumbar spine.

Nilai a menyatakan nilai konstanta, yaitu sebesar $-0,076$. Jika tidak ada nilai fraksi area trabekula mandibula atau nilai fraksi area trabekula mandibula sama dengan nol (0), maka nilai area sebesar $-0,076$. Nilai koefisien regresi yang diperoleh adalah $-0,145$, sehingga setiap penambahan 1 nilai fraksi area trabekula mandibula maka nilai $T$-score pada lumbar spine akan berkurang sebesar 0,145 . Nilai negatif pada koefisien regresi menunjukkan arah regresi. Dengan arah regresi yang negatif, menunjukkan bahwa jika terdapat kenaikan nilai fraksi area trabekula mandibula maka akan terjadi penurunan nilai $T$-score pada lumbar spine. Nilai t-hitung yang diperoleh adalah $-2,111$ dengan signifikansi ( $\alpha$ ) sebesar 0,046 atau kurang dari 0,05 sehingga terdapat pengaruh nilai fraksi area trabekula mandibula terhadap nilai $T$-score pada lumbar spine yang bermakna secara statistik.

\section{PEMBAHASAN}

Struktur tulang dibedakan menjadi dua macam, yaitu tulang kortikal (korteks) dan tulang trabekula. Korteks merupakan bagian yang tersusun padat (compact) dan keras (hard). Jaringan ini memiliki kerapatan yang tinggi. Korteks menyusun diafisis dari semua tulang panjang dan lapisan terluar dari semua tulang pendek, tulang pipih, dan tulang yang tidak beraturan. Tulang trabekula disebut juga tulang cancelous. Tulang trabekula merupakan bagian tulang yang nampak seperti karang (spongy) dan ditemukan di dekat ujung semua tulang panjang, serta di regio tengah tulang vertebral. ${ }^{11}$

Tabel 1. Hasil uji regresi linear dari nilai fraksi area terhadap nilai T-score pada lumbar spine

\begin{tabular}{lc}
\hline Uraian & Keterangan \\
\hline$R$ & 0,403 \\
$\mathrm{R}^{2}$ & 0,162 \\
$\mathrm{~F}$ hitung & 4,455 \\
$\mathrm{a}$ & $-0,076$ \\
$\mathrm{~b}$ & $-0,145$ \\
$\mathrm{t}$ hitung & $-2,111$ \\
$\mathrm{a}$ & 0,046 \\
\hline
\end{tabular}

Kualitas tulang merupakan suatu manifestasi dari arsitektur (geometri tulang, mikroarsitektur, ketebalan korteks, dan konektivitas trabekula), matriks, serta mineralisasi tulang. Kandungan mineral tulang atau bone mineral density menentukan kepadatan tulang sebagaimana ditunjukkan pada Gambar 3. Kepadatan tulang memiliki korelasi tinggi dengan resiko fraktur dan dapat digunakan oleh klinisi untuk menentukan kebutuhan intervensi farmakologis bagi pasien. ${ }^{12}$

Penyerapan sinar- $X$ oleh jaringan bergantung pada kualitas berkas sinar- $X$, karakter atom penyusun jaringan, densitas jaringan, dan ketebalan struktur yang di tembus. Jumlah kalsium dalam tulang mempengaruhi penyerapan sinar- $X$ pada tulang. Penurunan volume tulang yang termineralisasi berakibat pada penurunan kalsium tulang dan menurunkan penyerapan sinar- $X$, sehingga pengeroposan tulang yang mengakibatkan perubahan struktur tulang tersebut dapat diamati pada citra radiograf. Citra tulang pada radiograf dapat merefleksikan kepadatan tulang, histologi, dan morfologi bagian skeletal yang diperiksa. Prinsip deteksi osteoporosis pada radiograf adalah peningkatan radiolusensi, perubahan mikrostruktur tulang yang meliputi pembentukan lubang (porositas) trabekula, dan penipisan korteks yang pada akhirnya berakibat pada perubahan morfologi tulang, yaitu perubahan bentuk dan fraktur. ${ }^{13}$

Analisis regresi linier menghasilkan nilai korelasi dengan tingkat sedang antara fraksi area trabekula mandibula dengan nilai $T$-score pada lumbar spine $(R=0,403)$. Nilai korelasi parameter pada penelitian ini lebih kuat daripada parameter yang digunakan pada penelitian sebelumnya, yaitu parameter tekstur trabekula mandibula yang dikorelasikan dengan nilai kepadatan tulang.pada lumbar spine. ${ }^{11}$ Hal tersebut kemungkinan berkaitan dengan ketidakseimbangan dalam proses remodelling tulang pada penderita osteoporosis, dimana aktivitas osteoklas yang meresorpsi tulang lebih tinggi daripada aktivitas osteoblas yang membentuk tulang baru. Kondisi tersebut mengakibatkan terjadinya perforasi pada plate trabekula, sehingga konektivitas trabekula menjadi menurun, yang pada penelitian ini ditunjukkan dengan peningkatan fraksi area mandibula yang tampak pada radiograf periapikal. 


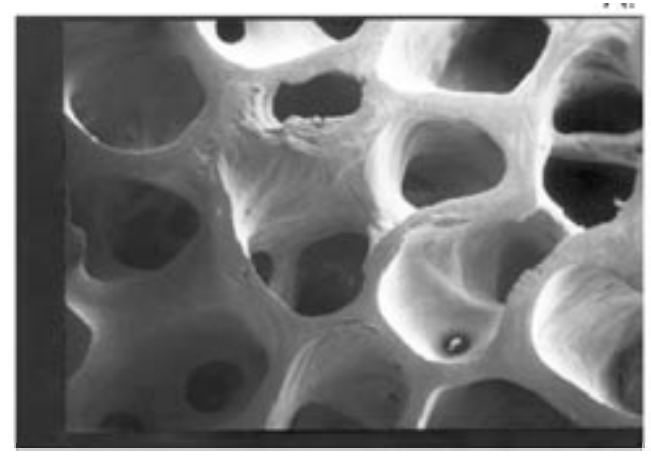

(A)

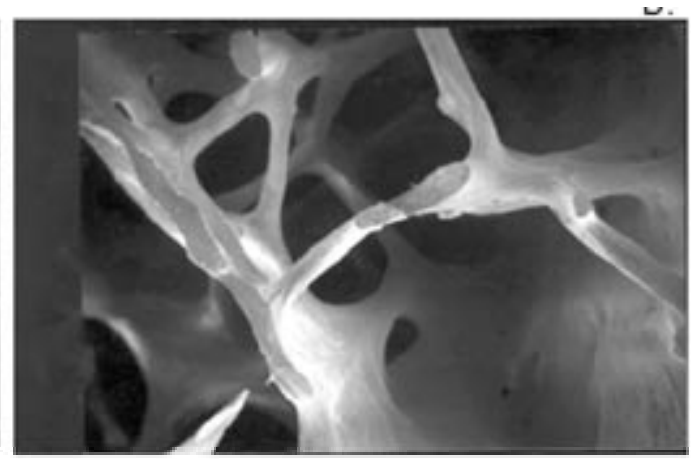

(B)

Gambar 3. Tulang trabekula pada (A) tulang normal dan (B) tulang yang mengalami osteoporosis ${ }^{11}$

Nilai fraksi area diperoleh dengan mengukur fraksi area dalam ROI. Ukuran ROI berbedabeda untuk citra radiograf yang berbeda. Jika kepadatan tulang menurun, maka akan terbentuk perforasi yang mengindikasikan bahwa trabekula tulang tidak terkoneksi dengan baik. Perforasi ini ditunjukkan dengan lebih jelas ketika dilakukan proses deteksi tepi canny terhadap citra radiograf periapikal digital. Dengan demikian, semakin rendah kepadatan tulang, maka akan terbentuk perforasi yang lebih banyak. Hal ini mengakibatkan terbentuknya area-area kecil dengan jumlah lebih banyak pada trabekula mandibula. Berdasarkan hasil uji statistika, nilai $T$-score yang menyatakan kepadatan tulang pada lumbar spine berkorelasi negatif dengan nilai fraksi area trabekula anterior rahang bawah.

Penelitian sebelumnya ${ }^{14,15}$ menunjukkan bahwa citra radiograf periapikal rahang atas dan rahang bawah berpotensi untuk dikembangkan sebagai indikator osteoporosis. Analisis yang digunakan pada penelitian sebelumnya berupa jumlah dan panjang strut yang diekstrak dari regio tertentu. Jumlah node terminus/mm strut tampak lebih rendah pada tulang yang osteoporosis dibandingkan dengan tulang normal. Kondisi ini menggambarkan bahwa trabekula pada pasien osteoporosis sebagian besar tidak terkoneksi, sehingga hanya sedikit terminus yang terhubung satu dengan yang lain. Terminus adalah akhir dari strut trabekula, sedangkan node adalah simpul pertemuan dua atau lebih terminus dalam satu strut. Penelitian ini menunjukkan kesesuaian dengan hasil penelitian sebelumnya ${ }^{14}$ tersebut.

Penelitian ini hanya menggunakan ROI dari radiograf periapikal regio anterior mandibula. Perlu dilakukan penelitian dengan menggunakan $\mathrm{ROI}$ dari radiograf periapikal posterior untuk menentukan area mana yang sesuai untuk dijadikan parameter prediktor osteoporosis. Fraksi area hanya berpengaruh $16,2 \%$ terhadap $T$-score pada lumbar spine, sedangkan sisanya $(83,8 \%)$ dipengaruhi oleh variabel lain, sehingga perlu dilakukan penelitian menggunakan variabel lain sebagai prediktor kepadatan tulang pada lumbar spine. Meskipun demikian pengaruh fraksi area trabekula rahang bawah terhadap nilai $T$-score pada lumbar spin tampak bermakna secara statistik.

Pada hasil penelitian ini, korelasi antar variabel yang digunakan lebih kuat dibandingkan dengan penelitian sebelumnya, ${ }^{16,17}$ dimana korelasi yang dihasilkan antara parameter run length dengan nilai kepadatan tulang berada pada rentang sangat lemah hingga sedang $(0,00 \leq R \leq 0,599)$. Metode dan tempat pengukuran yang berbeda menghasilkan kekuatan korelasi yang lemah. Kepadatan tulang pada area tertentu merupakan prediktor utama fraktur pada area tersebut. Seseorang dengan osteoporosis pada spine belum tentu menderita osteporosis pada femoral neck (pangkal tulang paha), demikian juga di mandibula.

Upaya untuk dapat memprediksi osteoporosis secara dini masih berpeluang untuk dikembangkan karena osteoporosis adalah penyakit sistemik. Keterbatasan fasilitas DEXA sebagai standar baku emas pemeriksaan kepadatan tulang 
terutama pada lumbar spine dan hip meningkatkan peluang untuk mengembangkan metode deteksi osteoporosis khususnya melalui rahang bawah yang memiliki ketersediaan yang lebih luas, dengan biaya pemeriksaan yang lebih murah.

\section{KESIMPULAN}

Kesimpulan dari penelitian ini adalah fraksi area trabekula mandibula yang tampak pada radiograf periapikal anterior menunjukkan korelasi yang bermakna dengan kekuatan sedang terhadap nilai T-score pada lumbar spine. Penggunaan fraksi area sebagai prediktor T-score lumbar spine perlu dilakukan pengujian secara lebih komprehensif dengan menggunakan data yang lebih banyak.

\section{DAFTAR PUSTAKA}

1. Adams JE. Dual-energy X-ray absorptiometry. Med Radiol Diagnostic imaging Radiat Oncol. 2008; 2: 105 - 124.

2. Kemenkes RI. Pedoman pengendalian osteoporosis. Keputusan Menteri Kesehat Republik Indones No 1142/Menkes/SK/ XII/2008. 2008; (Pedoman Pengendalian Osteoporosis).

3. PriyanaA. Peran pertanda tulang dalam serum pada tata laksana osteoporosis. Universa Med. 2007; 26.

4. Blake GM, Fogelman I. The role of DXA bone density scans in the diagnosis and treatment of osteoporosis. Postgr Med J. 2007; 83: 509 $-517$.

5. Licks R, Licks V, Ourique F, Bittencourt HR, Fontanella V. Development of a prediction tool for low bone mass based on clinical data and periapical radiography. Dentomaxillofacial Radiol. 2010; 39: 224 - 230.

6. Ishii K, Taguchi A, Nakamoto T, Ohtsuka M, Sutthiprapaporn P, Tsuda M, Kodama I, Kudo Y, Sumida H, Suei Y, Tanimoto K. Diagnostic efficacy of alveolar bone loss of the mandible for identifying postmenopausal women with femoral osteoporosis. Dentomaxillofac Radiol. 2007; 36: $28-33$.
7. Taguchi A, Otsuka M, Tsuda M, Nakamoto T, Kodama I, Inagaki K, Noguchi T, Kudo Y, Suei $\mathrm{Y}$, Tanimoto K. Risk of vertebral osteoporosis in post-menopausal women with alterations of the mandible. Dentomaxillofac Radiol. 36: 143 -148 .

8. Watanabe PCA, Issa JPM, de Olivera TM, Monteiro SAC, Iyomasa MM, Regalo $\mathrm{SCH}$, Siessere S. Morphodigital study of the mandibular trabecular bone in panoramic radiograph. IntJMorphol. 2007; 25(4): 875 880.

9. Whaites E. Essential of dental radiography and radiology. 4th ed. London: Churchill Livingstone Elsevier; 2007.

10. Lestari S, Suparta GB, Kertia N. The correlation between texture parameter of mandible trabecullar bone with the bone mass density value frame of theory. In: The 7th ICBEMA BME-Days 2012, November 9th10th. Serpong (BSD City): Institut of Electrical and Electronics Engineers, Inc.; 2012. 107 110.

11. Jepsen KJ. Systems analysis of bone. Wiley Interdiscip Rev Syst Biol Med. 2009; 1: 73 88.

12. National Osteoporosis Foundation. Clinician's guide and treatment. Washington DC: BoneSource; 2008.

13. Ayoub WT. Osteoporosis: clinical guidance for prevention, diagnosis, and management. In: Gueldner SH, Grabo TN, Newman ED, and Cooper DR, editor. Diagnostic Test and Interpretation. New York: Spinger Publishing Company; 2008. $33-40$.

14. Jergas M. Medical radiology. Diagnostic Imaging and Radiation Oncology. In: Baert AL, Brady LW, Heilmann HP, Knauth M, Molls M, Nieder $\mathrm{C}$, et al, editors. Heidelberg: Spinger; 2008. 77-104.

15. Faber TD, Yoon DC, Service SK, White SC. Fourier and wavelet analyses of dental radiographs detect trabecular changes in osteoporosis. Bone. 2004; 35(2): $403-411$. 
Majalah Kedokteran Gigi Indonesia. April 2017; 3(1): 43 - 50

ISSN 2460-0164 (print)

ISSN 2442-2576 (online)

16. Sela El, Widyaningrum R. Osteoporosis detection using important shape-based features of the porous trabecular bone on the dental x-ray images. Int J Adv Comput Sci Appl. 2015; 6: $247-250$.

17. Widyaningrum $\mathrm{R}$, Lestari $\mathrm{S}$. The correlation between mandible trabecular texture parameter on panoramic radiograph with bone mass density. Proc Int Symp oral Dent Sci. 2013; 206 - 214. 